\title{
Diversity of archaeal and bacterial communities on exfoliated sandstone from Portchester Castle
}

(UK)

Elisabetta Zanardini ${ }^{1,2^{*}}$, Eric $\mathrm{May}^{3}$, Robert Inkpen ${ }^{4}$, Francesca Cappitelli ${ }^{5}$,. Colin Murrell ${ }^{6}$ and Kevin J. Purdy ${ }^{1}$

${ }^{1}$ School of Life Sciences, University of Warwick, Coventry, UK.

${ }^{2}$ Department of Science and High Technology, University of Insubria, Como, Italy.

${ }^{3}$ School of Biological Sciences, University of Portsmouth, Portsmouth, UK.

${ }^{4}$ Department of Geography, University of Portsmouth, Portsmouth, UK.

${ }^{5}$ Dipartimento di Scienze per gli Alimenti, la Nutrizione e l'Ambiente, Università degli Studi di Milano, Milan, Italy.

${ }^{6}$ School of Environmental Sciences, University of East Anglia, Norwich Research Park, Norwich, UK.

\section{* Corresponding author}

Elisabetta Zanardini

Present address:

Department of Science and High Technology

University of Insubria, Como, Italy

Tel +390312386661

Fax +390312386119

Elisabetta.Zanardini@uninsubria.it 


\begin{abstract}
30 Abstract
In this study exfoliated sandstone samples from Portchester Castle were investigated using scanning electron microscopy (SEM) and energy dispersion X-ray (EDX) analyses to observe stone surface colonisation, geomorphological structure and to assess damage. Archaeal and bacterial diversity were assessed using cultivation-dependent and cultivation-independent methods. SEM analysis showed that sandstone had high levels of stone decay. There was considerable weathering of the minerals associated with biofilms containing microbes with various cellular morphologies. Microorganisms were especially prevalent in pores, cavities and in the heavily decayed parts of the minerals, and some etching was seen. EDX analyses indicated microbes were associated with the sheet structures of aluminium-containing phyllosilicate minerals, most likely glauconite. Microbial colonisation was preferentially concentrated within specific sheets of the mineral structure. Isolation studies revealed the presence of Bacillus and Arthrobacter that appeared to be well adapted to "extreme" environments, specifically these isolates were tolerant to high salt, high UV and oligotrophic conditions. Cultivationindependent studies using denaturing gradient gel electrophoresis fingerprinting of bacterial and archaeal 16S rRNA gene fragments showed a more complex community. Chloroflexi, Actinobacteria, Deinococcus, $\alpha$ - and $\beta$-proteobacteria, Cyanobacteria and Bacteroidetes and halophilic Archaea from the family Halobacteriaceae, were the predominant types of Bacteria and Archaea detected respectively.
\end{abstract}

49

\title{
Keywords
}

Stone biodeterioration, sandstone, exfoliation, SEM-EDX analyses, DGGE analyses, microbial diversity 


\section{Introduction}

Cultural heritage artefacts are affected by chemical and physical processes that can modify their structure and composition. Microorganisms associated with such artefacts are known to cause deterioration in organic material as well as inorganic materials such as stonework. A wide variety of microorganisms, especially bacteria and fungi, have been found on rocks and the stonework of historic monuments and buildings (McNamara and Mitchell 2005; Crispim and Gaylarde 2005; Gorbushina 2007; Ranalli et al. 2009; Scheerer et al. 2009; May 2010; Cappitelli et al. 2012).

Biodeterioration processes result from a complex interaction of microorganisms with the surface material, together with environmental and chemical factors that influence the aggressiveness of the process. Stone pore spaces and cavities protect microbial communities from solar radiation and desiccation, as well as providing mineral nutrients, moisture and a growth surface. In addition, when a biofilm is present, its extracellular polysaccharides provide further protection against a variety of environmental stresses, such as UV radiation, changes in $\mathrm{pH}$, osmotic shock and desiccation and reduce the penetration of antimicrobial agents (Alakomi et al.2006).

An appropriate assessment of stone biodeterioration and weathering effects requires a combination of microbiological, surface analysis and material characterization techniques. This typically involves the identification of the major types of microorganisms present, microscopic observations of the biofilm/material interface, elemental and mineral analysis of the damaged material and assessment of the morphology of the decay. Among the different methods for material characterization and surface analysis, scanning electron microscopy (SEM) and energy dispersion Xray analysis (EDX), are two of the most useful techniques for assessing both biotic and abiotic aspects of weathering and biodeterioration on cultural heritage materials.

SEM allows surface characterization at a high resolution, permitting visualisation of the microorganisms involved, their chemical and mechanical effects and the extent of biodeterioration. In previous studies on cultural heritage sites, SEM has revealed the microbial community as a complex interacting system, present in epilithic and endolithic zones that can be detrimental to monument stone. Effects on mineral species inside fissures and possible chemical changes are, in various ways, determined by the nature of the colonizing microbial populations (Herrera et al. 2009; de los Rios and Ascaso 2005; Polo et al. 2010).

From a biological point of view, a deeper understanding of the nature of the microbial community involved in these biodeterioration processes has improved in the last few decades with the application of molecular biological methods. Such techniques complement and expand the information on the resident microbes, which previously had been gathered by conventional microbial identification methods. Some studies have focused on the analysis of the structure of the colonising microbial communities, on the optimisation of molecular techniques in the field and on the detection of specific biodeteriogenic agents in the alterations. Other studies revealed the presence of novel microorganisms, which had never been detected in these environments before. Many investigations have been performed on objects in indoor environments such as wall paintings, frescoes and cave paintings; others on outdoor stoneworks of artistic and historical significance (Daffonchio et al. 2000; Urzì et al. 2001; Alonso-Vega et al. 2011; Piñar et al. 2001; Portillo et al. 2009; Saiz-Jimenez et al. 2011; Gurtner et al. 2000; Ripka et al. 2006; Abdulla et al. 2008; Giacomucci et al. 2011). There is still a clear need for in-depth investigation of the microbial species involved, in order to evaluate their role in biodeterioration. The need to identify the members of the microbial community that cause biodeterioration and to understand their specific roles is crucial, in order to effectively protect monuments through appropriate conservation plans and to maintain a long-term conservation strategy of our historic and artistic patrimony (Ranalli et al. 2009; May 2010; Saiz-Jimenez et al. 2011). The overall aim of the work presented in this paper was to study the diversity and distribution of the microbial community associated with sandstone alterations (mainly exfoliations) of outdoor stonework at Portchester Castle near Portsmouth using a combination of microscopy techniques and microbiological and molecular analyses. Of particular interest was the occurrence of those types of organisms that may be adapted to the harsh stone environment with possible resistance to high salt concentration, oligotrophic conditions and radiation. 


\subsection{Description of study site}

Portchester Castle is a medieval castle built on a former Roman fort at Portchester to the east of Fareham, Hampshire, UK. It lies at the head of Portsmouth Harbour (see Fig.1a). It is uncertain exactly when the castle was built, although it was probably in the late 11th century. Purbeck limestone was used to build fortification walls of the inner keep and green sandstone can be found in its buttresses and decorative door and window arches. Many parts of the castle in sheltered areas have macroscopic signs of biological colonisation, especially lichens and green patinas. The sandstone contains a considerable amount of clay and shows extensive decay. The east fortification wall, which faces the sea, suffers from extensive erosion due to salt and wind action.

South-East England is close to continental Europe and experiences a climate consistent with air masses from both continental Europe and from depressions crossing the Atlantic, bringing cold spells in winter and hot, humid weather in summer. The relatively sheltered nature of the region relative to these Atlantic depressions means, however, that their impact is less than experienced across the western parts of the UK (Wheeler and Mayes 1997). The south coast of this region has higher sunshine than the UK average, at over 1,541 hours per year, with relatively low rainfall (mean annual rainfall for Southsea between 1961 and 1990 was $685 \mathrm{~mm}$ ) and relatively mild temperatures (annual mean temperature for Southampton 1961-1900 of $10.8^{\circ} \mathrm{C}$ ) (Wheeler and Mayes 1997). Coastal sea breezes at Portsmouth, however, provide an important additional source of salt spray in what is otherwise a relatively mild wind climate (Harrison 1976).

\subsection{Sandstone sampling at Portchester castle}

Samples of green sandstone were taken from two sampling sites on a window in Richard II's banqueting room within the keep of the castle (Fig. 1b). Sites 1 and 2 (Figs. 1c and 1d respectively) were to the lower right of the window and both showed extensive exfoliation (Fig. 1e). Three replicate samples (1 A, B, C and $2 \mathrm{~A}, \mathrm{~B}, \mathrm{C})$ were aseptically removed from each site in June 2009 from a surface area of $10 \mathrm{~cm}^{2}$. The samples were kept at $4^{\circ} \mathrm{C}$ until they were transported to the University of Warwick (UK) for further processing.

\section{Fig.1}

Green sandstone is classified as very fine sand, glauconitic lithic arenite, highly porous stone with a mineral composition of : Quartz $\left(\mathrm{SiO}_{2}\right) 48 \%$, Calcite $\left(\mathrm{CaCO}_{3}\right) 20 \%$, Glauconite $14 \%$, Limonite 6\%, fine grained rock fragments $12 \%$ and occasional Muscovite and Felspar (Lewis 1987). Texture is composed by dominant grain size (1/16-1/18 mm), moderately to well-ordered, and porosity is $32.3 \%$. The high porosity of the sandstone permits relatively easy ingress of fluids and microbes into the matrix of the sandstone whilst the grain size provides a relatively large surface for microbes to colonize within the sandstone. The chemical composition of the sandstone provides a potentially resource-rich environment for microbial growth, particularly with the high concentration of glauconite containing iron and potassium.

\subsection{Scanning electron microscopy analyses}

After collection, stone samples for SEM were fixed overnight in $4 \% \mathrm{v} / \mathrm{v}$ glutaraldehyde in $0.2 \mathrm{M}$ sodium cacodylate buffer, rinsed in buffer, and then fixed in $1 \% \mathrm{w} / \mathrm{v}$ osmium tetroxide in $0.2 \mathrm{M}$ sodium cacodylate buffer. After rinsing in distilled water, samples were dehydrated in a graded ethanol series (15 min holding time in 20\% v/v steps) from $30 \%$ to absolute alcohol and then transferred to absolute acetone. After critical point drying in a Polaron Thermocirculator E3500, samples were glued to aluminium stubs and sputter coated with a gold/palladium mixture in a Polaron E5000 diode sputtering system. Samples were examined by SEM with a JEOL-JSM 6060 LV microscope attached to a X-Max EDX system (Oxford Instruments). 
The stone samples ( $\sim 0.5 \mathrm{~g}$ from all three aliquots pooled for the plating assays) were crushed using a sterile mortar and pestle and resuspended in $10 \mathrm{~mL}$ phosphate-buffered saline (PBS) amended with $0.01 \% \mathrm{w} / \mathrm{v}$ Tween 80 to facilitate removal of cells from stone particles (Lewis et al. 1988). Viable aerobic heterotrophic colony counts ( $\mathrm{CFU} \mathrm{g}{ }^{-1}$ stone sample) were determined in duplicate by plating out dilutions of the resuspended stone samples on R2A agar medium (Difco) and incubation at $25^{\circ} \mathrm{C}$ for 14 days (Reasoner and Geldreich, 1985; De Leo et al., 2012). Colonies representing all morphology types detectable on the plates were selected and restreaked to purity. Selected isolates were stored in glycerol at $-80^{\circ} \mathrm{C}$. As dormant cellular forms are often found in the bacterial community on stone we isolated spore-forming bacteria, samples were pasteurised at $80^{\circ} \mathrm{C}$ for $30 \mathrm{~min}$ and then plated onto nutrient agar, selected and screened as above.

\subsection{Isolation of halotolerant cultures}

In a separate study, $0.5 \mathrm{~g}$ crushed stone was suspended in $10 \mathrm{~mL}$ phosphate-buffered saline (PBS) and after manual shaking for $5 \mathrm{~min}$, the suspension was allowed to settle. The resultant supernatant $(0.1$ $\mathrm{mL}$ ) was diluted in PBS up to $10^{-6}$ and $0.1 \mathrm{~mL}$ aliquots of each dilution were spread onto BrII medium (Schostak and Krumbein, 1992) with two different high concentrations of $\mathrm{NaCl}(0.85$ and $1.5 \mathrm{M})$. After incubation at $30^{\circ} \mathrm{C}$ for 5-7 days, well-isolated colonies were picked and streaked onto Plate Count Agar (Oxoid) amended to the corresponding $\mathrm{NaCl}$ concentration. Purified cultures were maintained on slopes of the corresponding agar at $4^{\circ} \mathrm{C}$.

\subsection{Colony-PCR using bacterial 16S rRNA gene}

Colony PCR was carried out on all isolates in a total volume of $50 \mu$ Lusing a Tetrad 2 thermal cycling system (Bio-Rad, USA). Each PCR mix consisted of $1.5 \mathrm{mM} \mathrm{MgCl}_{2}, 1 \times$ PCR buffer (from 10X stock; Fermentas Inc. UK), $25 \mathrm{mM}$ dNTPs , $10 \mu \mathrm{M}$ each of 27F-1492R primers (Lane, 1991) (Invitrogen), 2.5 U Taq DNA polymerase (Fermentas Inc. UK), $20 \mathrm{mg} \mathrm{mL}^{-1} \mathrm{BSA}, 1 \mu \mathrm{L}$ DNA (10 to $30 \mathrm{ng} \mu^{-1}$ ). Cycling conditions were: a hot start at $95^{\circ} \mathrm{C}$ for $5 \mathrm{~min}$, followed by 30 cycles of: $95^{\circ} \mathrm{C}$ for $1 \mathrm{~min}, 55^{\circ} \mathrm{C}$ for $1 \mathrm{~min}$ and $72^{\circ} \mathrm{C}$ for $90 \mathrm{sec}$, with a final extension at $72^{\circ} \mathrm{C}$ for $8 \mathrm{~min}$. Production of the correctly sized amplicon ( $1500 \mathrm{bp}$ ) was checked using ethidium bromide stained agarose gel electrophoresis for each isolate and the purified PCR products were sequenced by the Molecular Biology Services, University of Warwick.

\subsection{DNA extraction from stone samples and DNA quantification}

DNA was extracted from $0.5 \mathrm{~g}$ of crushed stone samples using the FastDNA® SPIN Kit for soil (MP Biomedicals, USA) according to the manufacturer's instructions. The concentration of the extracted DNA was estimated either by running in a $1 \%(\mathrm{w} / \mathrm{v})$ ethidium bromide stained agarose gel along with a 1 kbp DNA ladder standard (Invitrogen) or by using a spectrophotometer (ND-1000; NanoDrop ${ }^{\mathrm{TM}}$, USA). Extracted DNA was stored at $-20^{\circ} \mathrm{C}$.

\subsection{Denaturing gradient gel electrophoresis (DGGE) analyses of $16 \mathrm{~S}$ rRNA genes}

The bacterial 16S rRNA genes in DNA from the samples were PCR amplified using a Tetrad2 thermal cycling system (Bio-Rad, USA). Bacterial 16S rRNA gene sequences were amplified directly using the primers 341F-GC/907R (Muyzer et al. 1993) while archaeal 16S rRNA gene sequences were amplified using a nested PCR, first with primer sets 21F-958R and then Parch519f-Arch915R-GC (Vissers et al. 2009). Each PCR mix consisted of $1.5 \mathrm{mM} \mathrm{MgCl}_{2}(1.5 \mathrm{mM}), 1 \mathrm{X}$ PCR buffer $(\mathrm{KCl}+$ $\mathrm{MgCl}_{2}$; Fermentas Inc. UK), $25 \mathrm{mM}$ dNTPs, $10 \mu \mathrm{M}$ of each primer (Invitrogen), $2.5 \mathrm{U}$ Taq DNA polymerase (Fermentas Inc. UK), $20 \mathrm{mg} \mathrm{mL}^{-1} \mathrm{BSA}, 10$ to $30 \mathrm{ng}$ DNA and water to $50 \mu \mathrm{l}$. Bacterial and archaeal 16S rRNA gene amplicons were analysed by DGGE (DCode ${ }^{\mathrm{TM}}$, system, Biorad, USA) using a 10\% (v/v) acrylamide/bisacrylamide in 1X TAE buffer with denaturant gradients of $30-70 \%$ for the bacterial community and $40-60 \%$ for the archaeal community, as 
described by Schäfer and Muyzer (2001). Gels were run in $1 \mathrm{X}$ TAE buffer at $60^{\circ} \mathrm{C}$ at a constant $84 \mathrm{~V}$ for 14 hours, then stained with SYBR(R) Gold (Invitrogen, UK) for $30 \mathrm{~min}$ and destained in water for $10 \mathrm{~min}$ before capturing the image using a UV trans-illuminator (Syngene, UK). Gel images were analyzed with GelCompar 3.0 (Applied Maths, Kortrijk, Belgium). For the bacterial DGGE individual bands of interest were excised from the DGGE gel, washed twice in sterile molecular-grade water and DNA eluted overnight at $4^{\circ} \mathrm{C}$ in a $1.5 \mathrm{~mL}$ microcentrifuge tube containing $20 \mu$ Lof molecular-grade water. The eluted DNA ( $5 \mu \mathrm{l})$ was re-amplified using the same PCR primers and conditions, PCR products were purified using the QiaQuick PCR purification system (Qiagen, USA) and sequenced at the Molecular Biology Services, University of Warwick.

It was not possible to excise individual bands from the archaeal DGGE gels, therefore we made an archaeal clone library to determine the identity of the archaea on these stoneworks. PCR products from the second round of archaeal-specific PCRs described above were cloned into a pGem-Teasy cloning kit (Promega) as described by the manufacturers. Insert-positive clones were screened for full-length inserts by colony PCR using vector-based primers and 20 clones selected for sequencing from each sample. In total 25 clones were sequenced successful at the Molecular Biology Services, University of Warwick.

\subsection{Phylogenetic analyses}

Sequenced 16S genes from isolates and DGGE analysis were analysed using BLAST (http://www.ncbi.nlm.nih.gov/BLAST; Altschul et al. 1990). The sequences were aligned with related sequences from reference strains and environmental clones using ClustalX (Version 1.8) (Thompson et al. 1997). Neighbour-Joining phylogenetic trees were generated using MEGA4 (Tamura et al. 2007).

\subsection{Sequence accession numbers}

All sequences have been submitted to GenBank. Accession numbers; bacterial isolates KU244567600; bacterial DGGE bands KU244601-629; archaeal clones KU244542-566.

\section{Results}

\subsection{SEM observations}

SEM analysis of samples from Sites 1 and 2 showed that the sandstone had substantial stone decay with considerable weathering of minerals (Fig. 2). Biofilms with diverse microbial structures, commonly rods and occasionally filamentous (probably actinomycetes) colonies, were observed covering the mineral surfaces. At both sites, microbial cells were frequently situated either between the grains of the mineral materials or below them in surface depressions (Fig. $2 \mathrm{~d}$ and g). The surfaces of the calcite crystals in Fig. 2 (a, b and c) appeared to have microbial activity on them, although this seems to have produced surface etching across the whole crystal surface rather than preferential removal of material.

Both glauconite and muscovite are phyllosilicates and members of the mica family (Read, 1970). They are silicates of aluminium and potassium and crystallize in a monoclinic system, tending to form hexagonal sheet structures.

Stone samples were sent to Warwick Analytical Service (Exeter Analytical Ltd, Warwick UK) for ICP elemental analysis and results showed that the most abundant elements, expressed in $\mathrm{mg} / \mathrm{g}$ of crushed stone, were: Al (7.2-18.5), Ca (16.1-141.6), Fe (5.1-14.6), Na (2.8-3.8), K (8.03-15.6), Si (19.2-35.1). The high concentration of $\mathrm{Al}$ and the presence of sheet-like structures (top right of Fig. 3a) implies the presence of a phyllosilicate, most likely glauconite. In this image of the phyllosilicate (Fig. 3a) where the edge of the sheet structures can be seen, it would appear that microbial activity is preferentially concentrated within specific sheets of the mineral structure. The microbes seem to be associated with the jagged edges of the sheets and there are very few, if any, microbes on the larger, flat surfaces of these crystals. 
Fig. 3

\subsection{Heterotrophic plate counts and identity of bacterial isolates}

The heterotrophic bacterial counts (R2A medium) were $5.52 \times 10^{5} \mathrm{CFU} / \mathrm{g}$ stone (13 isolates, 7 pigmented) and $7.18 \times 10^{3}$ after pasteurisation ( 5 isolates, 2 pigmented) in sample 1 and $1.94 \times 10^{5}$ CFU/g stone (16 isolates, 9 pigmented) and $8.25 \times 10^{2}$ after pasteurisation (4 isolates, 1 pigmented) in sample 2 .

Thirty-eight isolates were obtained and most of them were yellow or red pigmented (Supplementary Fig.1) and all the isolates were Gram positive, oxidase- and catalase-positive.

In a separate experiment, halotolerant bacteria (NaCl-tolerant and bacteria) able to grow at $\mathrm{NaCl}$ concentrations of 0.85 and $1.5 \mathrm{M}$ were also isolated.

Colony PCR, using general bacterial 16S rRNA gene primers, was carried out on all isolates. The purified PCR products were sequenced using forward primer 341F. The 16S rRNA gene sequences of isolates were compared and clustered if $>99 \%$ identical. This phylogenetic analysis using BLAST generated distinct isolates. The closest related species are shown in Table S1 supplementary data. The isolates were analysed phylogenetically along with the sequenced DGGE bands (Figs 4 and 5). Most of the R2A and halotolerant isolates grouped in two main groups, Actinobacteria (mainly represented by the genera Arthrobacter, Micrococcus, Rubrobacter) and Firmicutes (Bacillus sp.) (Fig. 5).

\section{$3.316 S$ rRNA gene profiles from DGGE analyses}

DGGE analyses of 16S rRNA gene amplicons of Bacteria and Archaea showed very similar profiles in samples 1 and 2 and also there was very little difference between the DGGE profiles for the three replicates (Fig. 4A and B). A cluster analysis performed within GelComparII (whole profile Pearson's correlation coefficient) of the bacterial 16S rRNA gene DGGE profiles confirmed the high degree of similarity ( $\geq 60 \%$ ) between samples 1 and 2 (exfoliated sandstone) and also the similarity between the three replicates (Fig. 4C).

The archaeal 16S rRNA gene analysis by DGGE showed little difference between the samples, but indicated that there was less diversity than in the bacterial community. The key bands that were sequenced from the bacterial DGGE profiles are indicated in Fig 4A.

The phylogeny of these sequences and their closest identities identified by BLAST analysis are shown in Fig. 5 and Supplementary Table S2 supplementary data.

Fig. 4

Fig. 5

Most of the 16S rRNA gene sequences retrieved were related to 16S rRNA genes from heterotrophic and photosynthetic groups previously found on rock and stoneworks and also related to bacteria that are well-adapted to "extreme" environments, such as high salinity, high UV radiation, desiccation, oligotrophic conditions and high temperatures.

The archaeal community showed little diversity between samples as determined by DGGE analyses (Fig 4B), and this low diversity was reflected in the clone library analyses (Fig. 6) which indicate the archaeal community was dominated by members of the Halobacteriaceae, specifically Halococcus, with clones detected that clustered within the Thaumarchaeota Group C1a.2B (Sliwinski and Goodman 2004), which have been linked to ammonia oxidation.

Fig. 6 
In this study, the SEM analysis of the exfoliated samples from Portchester Castle showed that the sandstone has high levels of stone decay with considerable weathering of the minerals. Complex microbial communities and biofilms were commonly observed covering the mineral surfaces. The biofilms displayed diverse microbial structures which were developing in close contact with the stone material, confirming the ability of the stone-colonising microflora to cover and even penetrate deep into the stone. Biofilms provide protection from high light intensities and desiccation and the extracellular polymeric substances (EPS) that binds them can trap aerosols, dust, nutrients, minerals, and organic compound complexes and take up water from the air, releasing it under low relative humidity conditions. Stone moisture and nutrients increase while biofilms reduce stone porosity, water-uptake capacity, and evaporation (Christensen and Characklis 1990; Warscheid et al. 1993). SEM analysis revealed microbial cells with a wide range of different microbial morphologies. In both exfoliating stone samples analysed here, microbial cells were frequently situated either between the grains of the mineral materials or below them in surface depressions.

The features identified in the SEM images do bear some visually similarity in terms of morphology to the nanoforms produced by Viles and Moses (1998) in their experimental production of nanomorphologies using acidic solutions $(0.02 \mathrm{M} \mathrm{HCl})$. These similarities suggest that the etching on the calcite crystals may be affected by chemical activity as well as microbial activity. The morphologies found at the jagged edges of the crystal sheets does not, however, appear to match the forms found by Viles and Moses (1998). This suggests that these features are dependent upon microbial activity for their formation. The jagged edges imply that there is differential removal of material from the mineral. The high concentration of aluminium at the edges suggests that this element is not removed by microbial activity from the crystal structure. Thompson and Hower (1975) in their analysis of the mineralogy of glauconite pointed out that potassium, under conditions of acid dissolution, can be initially removed from the mineral at a very fast rate and can be interpreted as exchangeable potassium within the hydrated layers of the mineral structure. The location of this readily removed potassium may be related to the nanomorphologies observed, although further detailed SEM analysis is required to confirm this hypothesis.

Using cultivation-dependent techniques, only limited bacterial diversity was observed with most of the isolates from the exfoliated samples being of the genera Bacillus and Arthrobacter. Previous culturebased studies of sandstone samples have shown samples to be dominated by organisms such as Pseudomonas, Flavobacterium, Actinobacteria and Bacillus (Tayler and May 1991). Cultivable heterotrophic bacteria such as Arthrobacter, Bacillus, Micrococcus, Paenibacillus, Pseudomonas and Rhodococcus have been also identified as very common rock-inhabiting microorganisms (Gorbushina 2007) and Actinobacteria of genus Arthrobacter were detected in samples from outdoor historic Scottish monuments (Suihko et al. 2007). Cultivation-independent analysis using DGGE fingerprinting of both bacterial and archaeal 16S rRNA genes showed very similar profiles in the two samples and within the three replicates, but there was a greater diversity in the bacterial community compared to the archaeal community. Chloroflexi, Actinobacteria, Deinococcus, $\alpha$ - and $\beta$-Proteobacteria, Cyanobacteria and Bacteroidetes, and halophilic Archaea from the family Halobacteriaceae, were the predominant types of Bacteria and Archaea respectively. The presence of both phototrophic organisms that usually initiate colonization and heterotrophic bacteria that help establish a stable biofilm was observed. Cyanobacteria have been reported to be important deteriogens and can be detected on stonework using both traditional and molecular methods (Crispim and Gaylarde 2005).

Heterotrophic bacteria play an important role in the weathering of rocks and minerals and are readily isolated in large numbers from decaying stone. All stonework probably possesses sufficient organic matter from soil, dust, and dirt to sustain some heterotrophic activity. Moreover, many stone bacteria have a preference for low nutrient (oligotrophic) conditions (Tayler and May 1991). The widespread distribution of heterotrophic bacteria on decayed stone has been shown previously at Portchester Castle (Lewis 1987; Lewis et al 1988; Tayler and May 1991). Filamentous cells, presumably actinobacteria, were also observed in the SEM analyses presented here. A wide range of actinobacteria have been isolated from stone and these isolates have been shown to produce many hyphal filaments 
that can penetrate into the stone, producing patches of biofilm on stone particles and around stone pores, often interacting with salt crystals and causing mechanical damage. Another characteristic of these actinobacteria is that they have a particular capacity to survive adverse environmental conditions, especially low water availability and elevated temperatures (Abdulla et al. 2008; Urzì et al. 2001).

Molecular methods have previously confirmed the presence of Proteobacteria, Actinobacteria and Bacteroidetes strains on, as well as within, the upper layers of rock and other materials (bricks, mortar, mural paintings, plaster, roof tiles, etc.) (Gorbushina 2007). In addition, extremely halophilic archaea that are closely related to Halococcus have been detected in deteriorated ancient wall paintings in Austria and Spain (Piñar et al. 2001). Most of the microorganisms found in Portchester Castle samples are closely related to strains that are well adapted to "extreme" environments, especially high salinity, high UV radiation, low water availability, high temperatures and oligotrophic conditions. Some of the organisms detected by DGGE $(15,20 \mathrm{c}$ and 26 , see Fig. 5, 6) were closely related to the extremely radiation resistant Rubrobacter radiotolerans (Kausar et al. 1997; Jurado et al. 2012; Ettenauer et al. 2014.).

In conclusion, an integrated approach using microscopic observations together with cultivationdependent and cultivation-independent analyses revealed complex microbial colonisation in altered sandstone samples. DGGE profiles of $16 \mathrm{~S}$ rRNA genes also revealed surprisingly high bacterial biodiversity within the microbial community. However, diversity studies do not show which of these organisms are active, therefore functional gene analyses of specific target genes now need to be carried out to better understand the function of the microbial community colonising and altering cultural heritage stonework (Villa et al. 2015). Structural and functional analyses of the microbial communities altering our artistic and historical patrimony, and the identity and roles of the "key players" that cause damage, is vital to effectively protect and maintain long-term conservation of cultural heritage stonework.

\section{Acknowledgments}

This research was supported by Marie Curie-Intra European Fellowship (IEF): Biological agents that actively attack Cultural Heritage Stoneworks (BIOATTACH) (PIEF-GA-2009-235317). We thank English Heritage for permission to sample at Portchester Castle. Initial collaborative interactions supported by British Council-CRUI project (British-Italian Partnership Programme 2009). We also thank Dr Hélène Moussard for her help and support in the lab experiments.

\section{References}

Abdulla H., May E., Dewedar A., 2008. Characterisation of actinomycetes isolated from ancient stone and their potential for deterioration. Pol J Microbiol, 57, 213-20.

Alakomi H.L., Paananen A., Suihko M.L., Helander I.M., Saarela M. 2006. Weakening effect of cell permeabilizers on Gram-negative bacteria causing biodeterioration. Appl Environ Microbiol, 72, 4695-703.

Alonso-Vega P., Carro L., Martínez-Molina E., Trujillo M.E. 2011. Auraticoccus monumenti gen. nov., sp. nov., an actinomycete isolated from a deteriorated sandstone monument. Int J Syst Evol Microbiol, 61, 1098-103.

Altschul S.F., Gish W., Miller W., Myers E.W., Lipman D.J. 1990. Basic local alignment search tool. J Mol Biol, 215, 403-10.

Cappitelli F., Salvadori O., Albanese D., Villa F., Sorlini C. 2012. Cyanobacteria cause black staining of the National Museum of the American Indian Building (Washington, D.C., USA). Biofoul, 28, 25766. 
Christensen B.E., Characklis W.G. 1990. Physical and chemical properties of biofilms. In: Characklis W.G., Marshall K.C. (Eds), Biofilms, John Wiley \& Sons Inc, New York, pp.93-130.

Crispim C.A., Gaylarde C.C. 2005. Cyanobacteria and biodeterioration of cultural heritage: a review. Microb Ecol, 49, 1-9.

Daffonchio D., Borin S., Zanardini E., Abbruscato P., Realini M., Urzì C., Sorlini C. 2000. Molecular tools applied to the study of deteriorated artworks. In: Ciferri O., Tiano P., G. Mastromei G. (Eds). Of microbes and art: the role of microbial communities in the degradation and protection of cultural heritage, Kluwer Academic/Plenum Pub, New York, pp.21-38.

De Leo F., Iero A., Zammit G., Urzì C.E. 2012. Chemoorganotrophic bacteria isolated from biodeteriorated surfaces in cave and catacomb. Int J Speleology, 41, 2, 125-136.

de los Ríos A., Ascaso C. 2005. Contributions of in situ microscopy to the current understanding of stone biodeterioration. Int Microbiol, 8, 181-8.

Ettenauer J.D., Jurado V., Piñar G., Miller A.Z., Santner M., Saiz-Jimenez C., Sterflinger K. 2014. Halophilic microorganisms are responsible for the rosy discolouration of saline environments in three historical buildings with mural paintings. PLoS ONE, 9, 8, e103844, 1-13.

Giacomucci L., Bertoncello R., Salvadori O., Martini I., Favaro M., Villa F., Sorlini C., Cappitelli F. 2011. Microbial deterioration of artistic tiles from the facade of the Grande Albergo Ausonia \& Hungaria (Venice, Italy), Microb Ecol, 62, 287-98.

Gorbushina A.A. 2007. Life on the rocks. Environ Microbiol, 9, 1613-31.

Gurtner C., Heyrman J., Pinar G., Lubitz W., Rolleke S. 2000. Comparative analyses of the bacterial diversity on two different biodeteriorated wall paintings by DGGE and 16S rDNA sequence analysis. Int Biodet Biodegr, 46, 229-39.

Harrison S.J. 1976. The land and sea breezes of south Hampshire: a climatological review. J Metereol, $1,383-87$.

Herrera L.K., Videla H.A. 2009. Surface analysis and materials characterization for the study of biodeterioration and weathering effects on cultural property. Int Biodet Biodegr, -63, 813-22.

Jurado V., Miller A.Z., Villegas C.A., Laiz L., Saiz-Jimenez C. 2012. Rubrobacter bracarensis sp nov., a novel member of the genus Rubrobacter isolated from a biodeteriorated monument. Syst Appl Microbiol, 35, 306-309.

Kausar J., Ohyama Y., Terato H., Ide H., Yamamoto D.O. 1997. Phylogenetic alignment with members of the genus Arthrobacter, Gram-positive bacteria, and members of the family Deinococcaceae. Int J Syst Bacteriol, 47, 684-686.

Lane D.J. 1991. 16S/23S rRNA sequencing. In: Stackebrandt E., Goodfellow M. (Eds), Nucleic acid techniques in bacterial systematics, Wiley, New York, pp.115-75.

Lewis F.J. 1987. Investigations of bacteria on building stone and their role in stone decay. $\mathrm{PhD}$ thesis (CNAA). Portsmouth Polytechnic, Portsmouth, UK.

Lewis F.J., May E., Bravery A.F. 1988. Metabolic activities of bacteria isolated from building stone and their relationship to stone decay. In: Houghton D.R., Smith R.N., Eggins H.O.W. (Eds), Biodeterioration 7, Elsevier Appl Sci, London, pp.107-12. 
May E. 2010. Stone biodeterioration. In: Mitchell R., McNamara C.J. (Eds). Cultural heritage microbiology: fundamental studies in conservation science, ASM Press, Washington DC, pp.1-39.

McNamara C.J., Mitchell R. 2005. Microbial deterioration of historic stone. Front Ecol Environ, 3, 445-51.

Muyzer G., de Wall E.C., Uitterlinden Q.G. 1993. Profiling of complex microbial populations by denaturing gradient gel electrophoresis analysis of polymerase chain reaction-amplified genes coding for 16S rRNA. Appl Envir Microbiol, 59, 695-700.

Piñar G., Saiz-Jimenez C., Schabereiter-Gurtner C., Blanco-Varela M.T., Lubitz W., Rolleke S. 2001. Archaeal communities in two disparate deteriorated ancient wall paintings: detection, identification and temporal monitoring by denaturing gradient gel electrophoresis. FEMS Microbiol Ecol, 37,45-54.

Polo A., Cappitelli F., Brusetti L., Principi P., Villa F., Giacomucci L., Ranalli G., Sorlini C. 2010. Feasibility of removing surface deposits on stone using biological and chemical remediation methods. Microb Ecol, 60, 1-14.

Portillo C., Saiz-Jimenez C., Gonzalez J.M. 2009. Molecular characterization of total and metabolically active bacterial communities of "white colonizations" in the Altamira Cave, Spain Res Microbiol, 160, 41-7.

Ranalli G., Zanardini E., Sorlini C. 2009. Biodeterioration- including cultural heritage. In: Schaechter M. (Ed.), Encyclopedia of Microbiology, Elsevier, Oxford, pp. 191-205.

Read H.H. 1970. Rutley's elements of mineralogy (26th ed), George Allen and Unwin, London.

Reasoner D.J., Geldreich E.E. 1985. A new medium for the enumeration and subculture of bacteria from potable water. Appl Environ Microbiol.,49, 1, 1-7.

Ripka K., Denner E.B.M., Michaelsen A., Lubitz W., Piñar G. 2006. Molecular characterisation of Halobacillus strains isolated from different medieval wall paintings and building materials in Austria. Int Biodet Biodegr, 58, 124-32.

Saiz-Jimenez C., Cuezva S., Jurado V., Fernandez-Cortes A., Porca E., Benavente D., Cañaveras J.C., Sanchez-Moral S. 2011. Paleolithic art in peril: policy and science collide at Altamira Cave. Science, 334(6052), 42-3.

Schäfer H., Muyzer G. 2001, Denaturing Gradient Gel Electrophoresis in marine microbial ecology. Meth Microbiol, 30, 425-68.

Scheerer S., Ortega-Morales O., Gaylarde C. 2009. Microbial deterioration of stone monuments-an updated overview. Adv Appl Microbial, 66, 97-139.

Sliwinski M.K., Goodman R.M. 2004. Spatial heterogeneity of Crenarchaeal assemblages within mesophilic soil ecosystems as revealed by PCR-single-stranded conformation polymorphism profiling. Appl Environ Microbiol, 70, 1811-20.

Schostak V. and Krumbein_W. E. 1992. Occurrence of extremely halotolerant and moderate halophilic bacteria on salt impaired wall paintings. In: Delgado R., J., Henriques F., Telmo J. (Eds). Proceedings of the 7th International Congress on Deterioration and Conservation of Stone, LNEC, Lisbon, pp. 551560. 
Suihko M.L., Alakomi H.L., Gorbushina A., Fortune I., Marquartd J., Saarela M. 2007. 
586 Diversity of archaeal and bacterial communities on exfoliated sandstone from

587 Portchester Castle (UK)

588

589

Elisabetta Zanardini, Eric May, Robert Inkpen, Francesca Cappitelli, J. Colin Murrell and 590

\section{Highlights}

- Integrated approach revealed complex microbial colonisation in altered sandstone.

- Most of the microorganisms are well adapted to extreme environments.

- Identity of key players that cause damage is vital to conserve heritage stonework. 
599

600

601

602

603

604

605

606

607

608

609

610

611

612

613

614

615

616

617

618

619

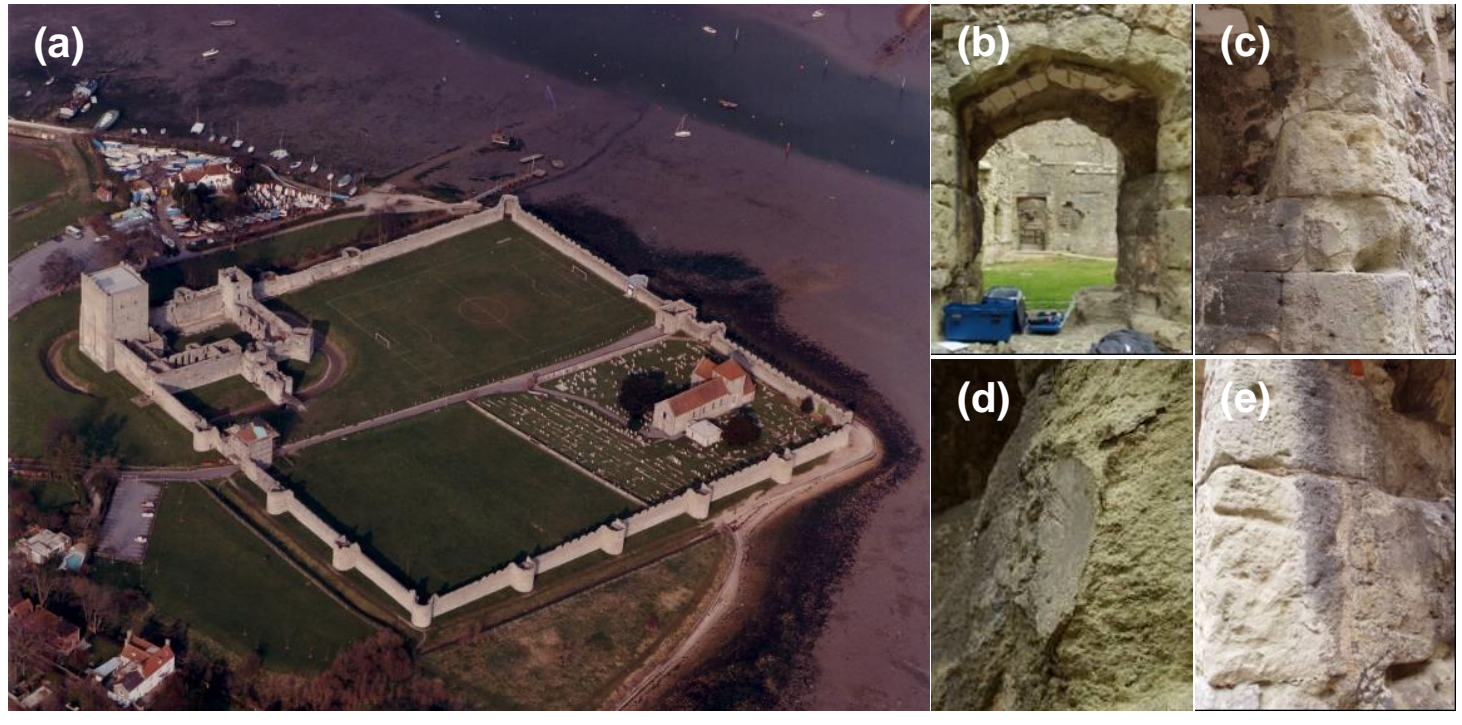

Figure 1 
620

621

622

623

624

625

626

627

628

629

630

631

632

633

634

635

636

637

638

639

640

641

642

Figure 2.
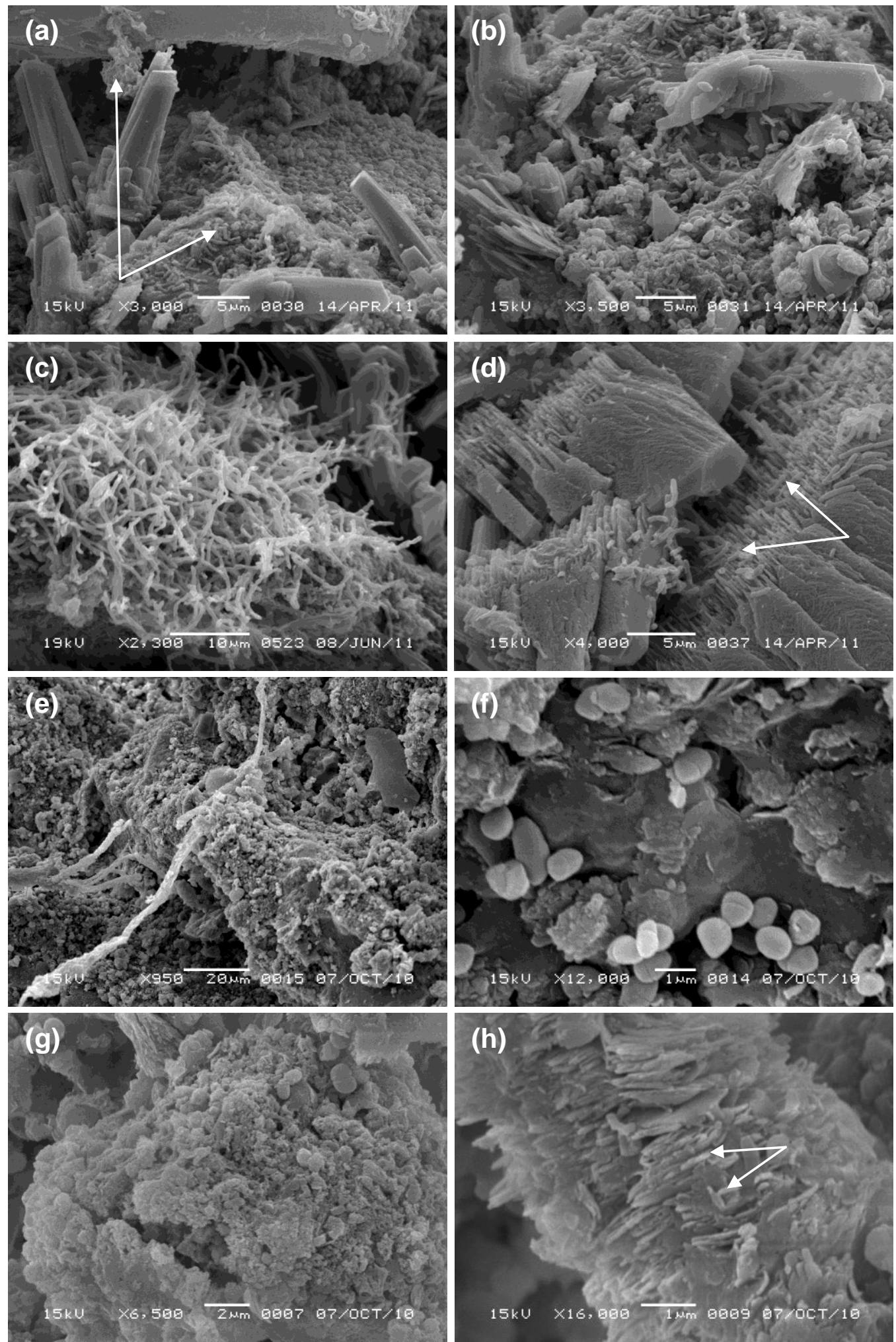

643 


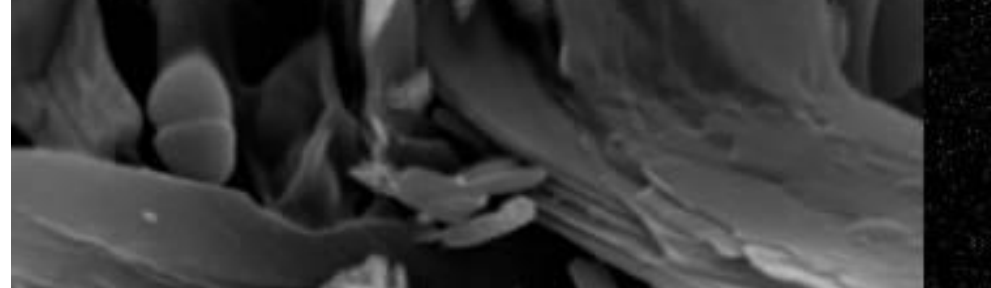

\section{Al}

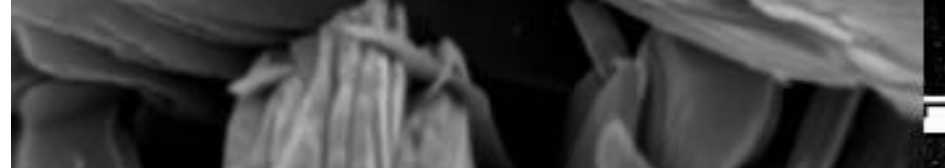

(c)
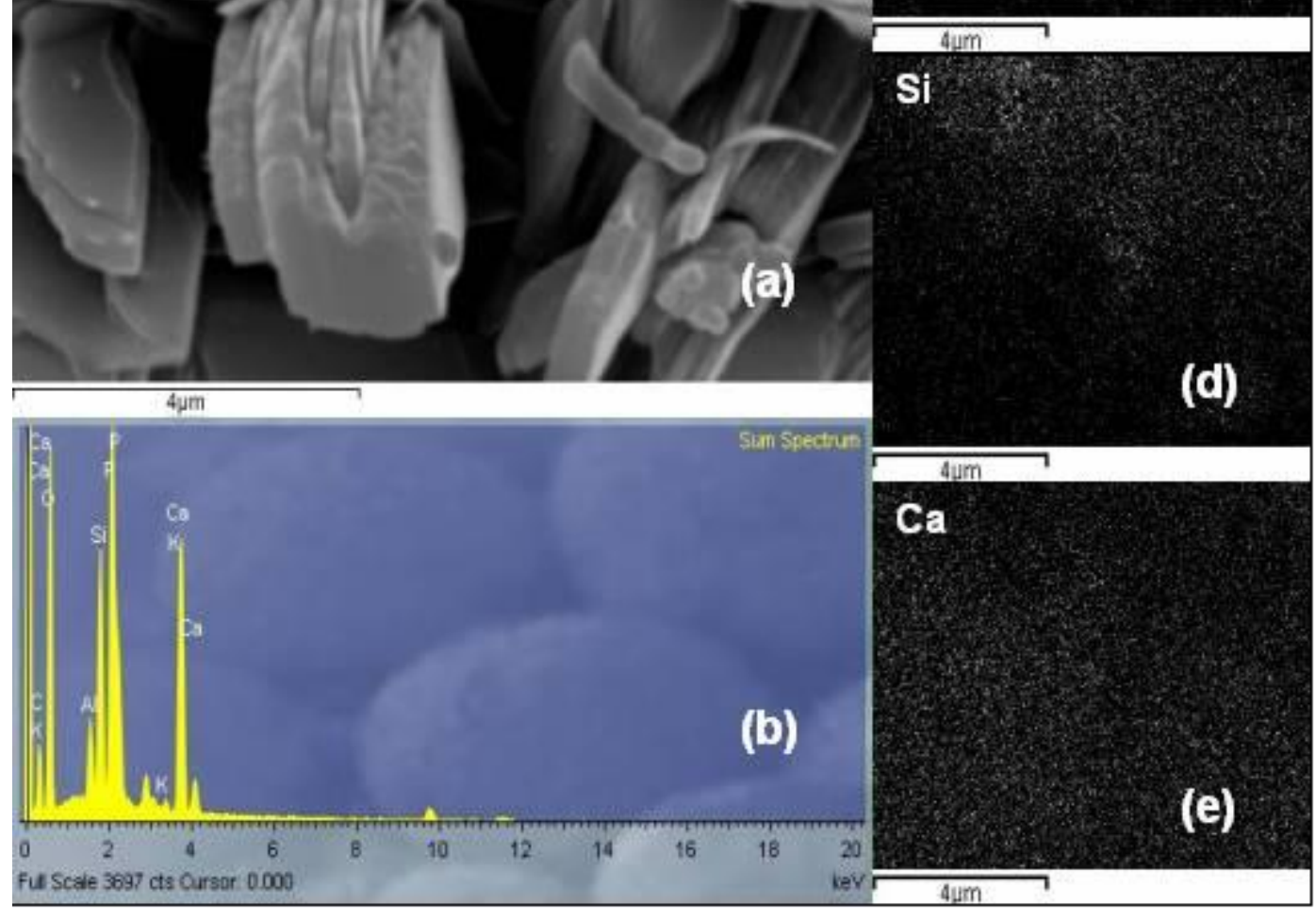

(d)

661

662

663 Figure 3

664

665

666

667

668

669

670

671

672

673 
A. Bacterial DGGE

$\begin{array}{lllllll}\mathrm{L} & 1 \mathrm{~A} & 1 \mathrm{~B} & 1 \mathrm{C} & 2 \mathrm{~A} & 2 \mathrm{~B} & 2 \mathrm{C}\end{array}$

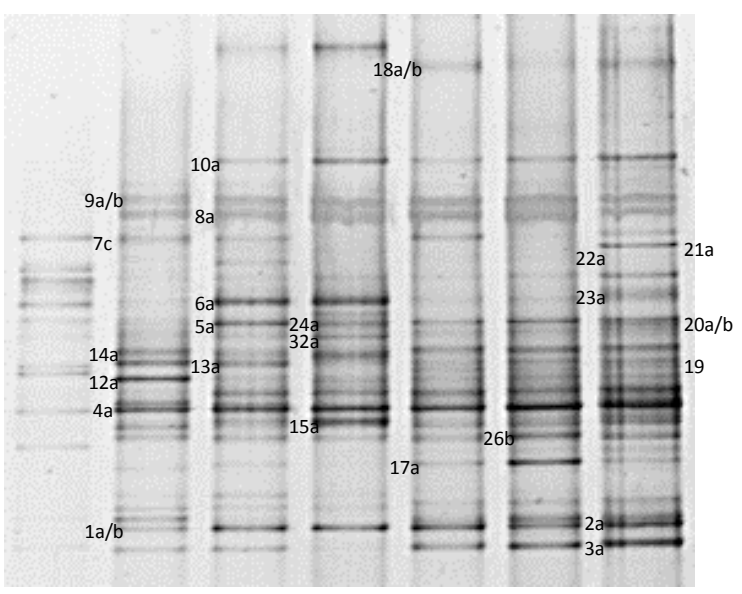

C. Cluster analysis of bacterial DGGE
B. Archaeal DGGE

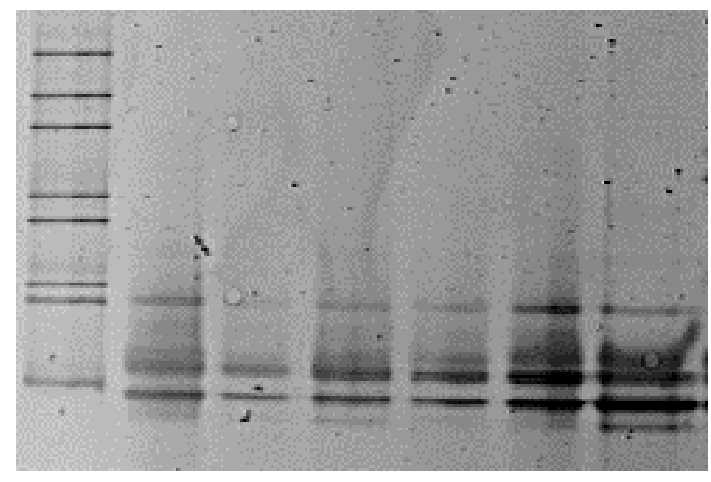

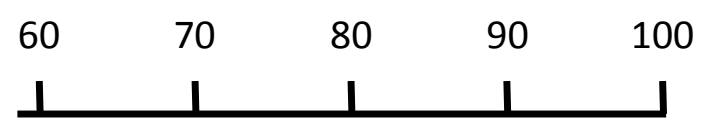

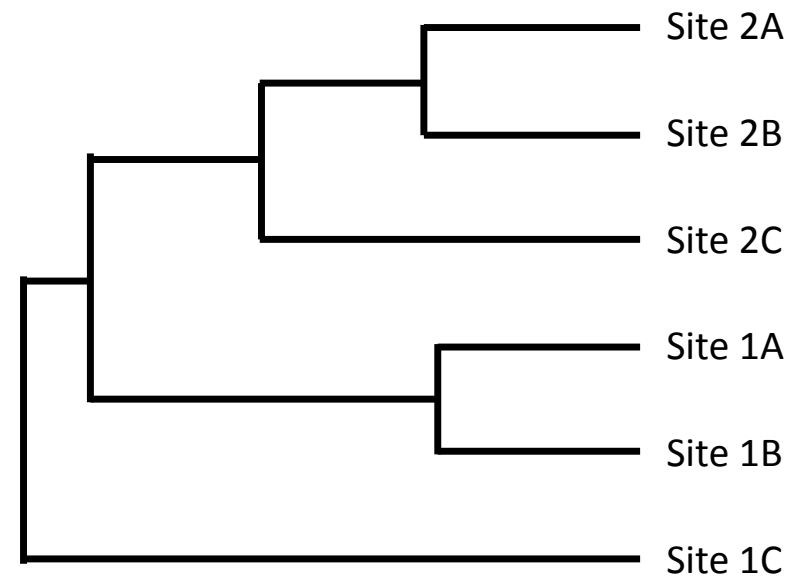




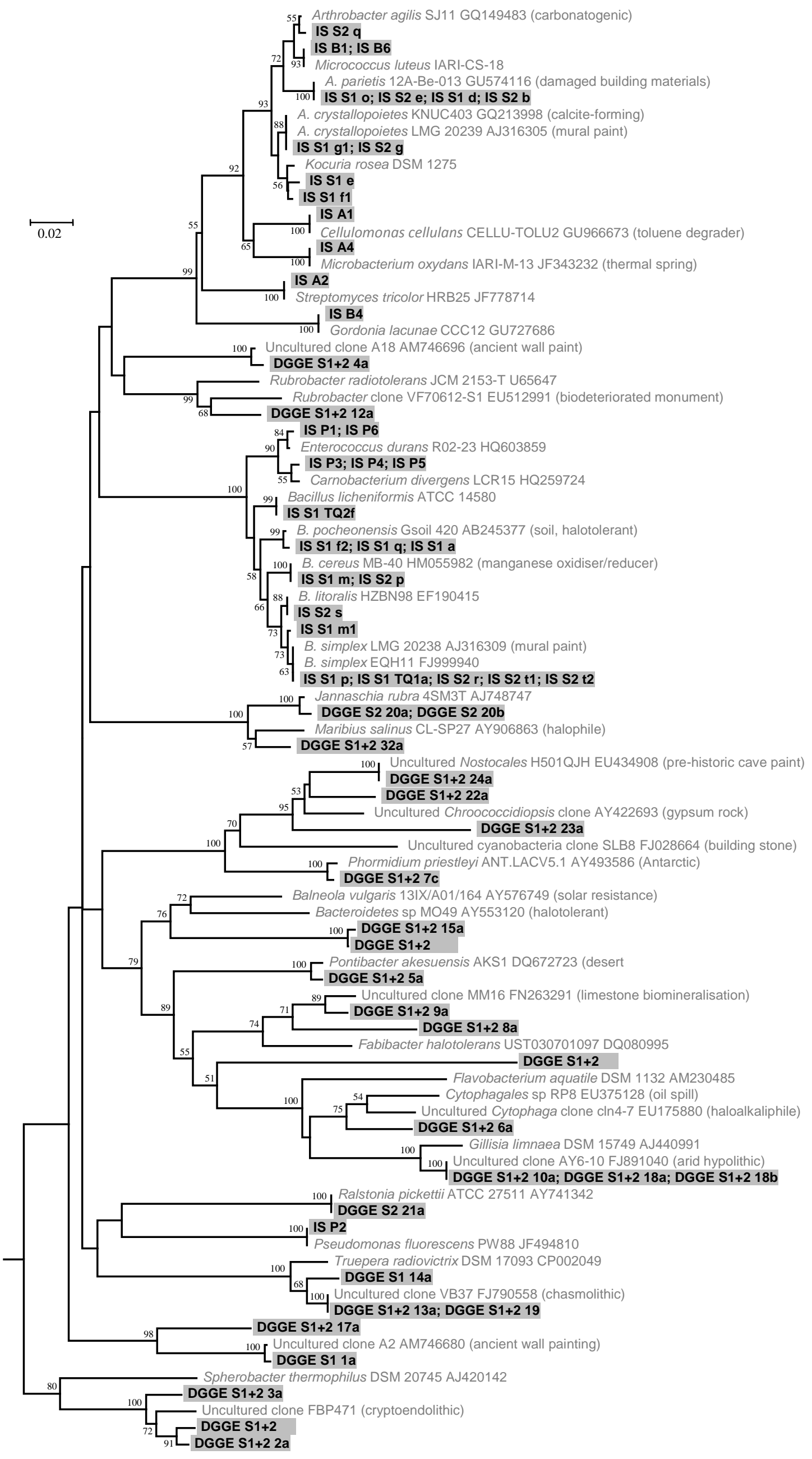


$676 \quad$ Figure 5

677 
678

679

680

$\operatorname{so2}, 4,6,11,21,26,28,35,38$

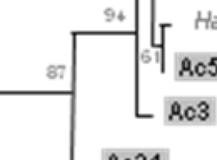

Lo24

T- Halococcus clone 24 FN435863 (stonew ork salt efflorescence)

我

Halococcus clone H6-K5 A 291421 (ancient wall paint)

- Halococcus clone 16 FN435871 (stonew ork salt efflorescence)

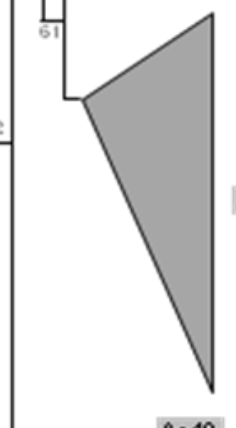

Rc48

8c7, $8,13,19,22,32,40,45$

Halococcus clone 46 FN435879 (stonew ork salt efflorescence)

Habobaterium noricense clone Py05.4 AJ270236 (salt mine brine)

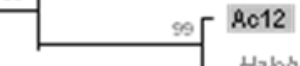

L Halobacterium. clone 83 FN435850 (stonework salt efflorescence) Thaumarchaea-like clone MGS6 AY522874 (soil)

1. 8014

Figure 6 
681

682
Figure 1 (supplementary data)
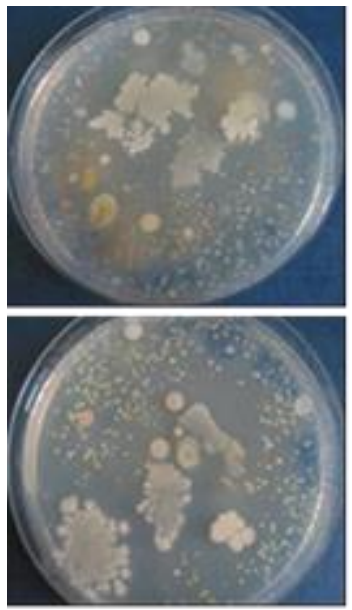
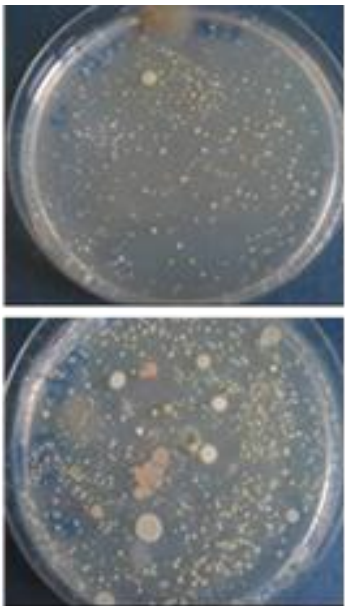

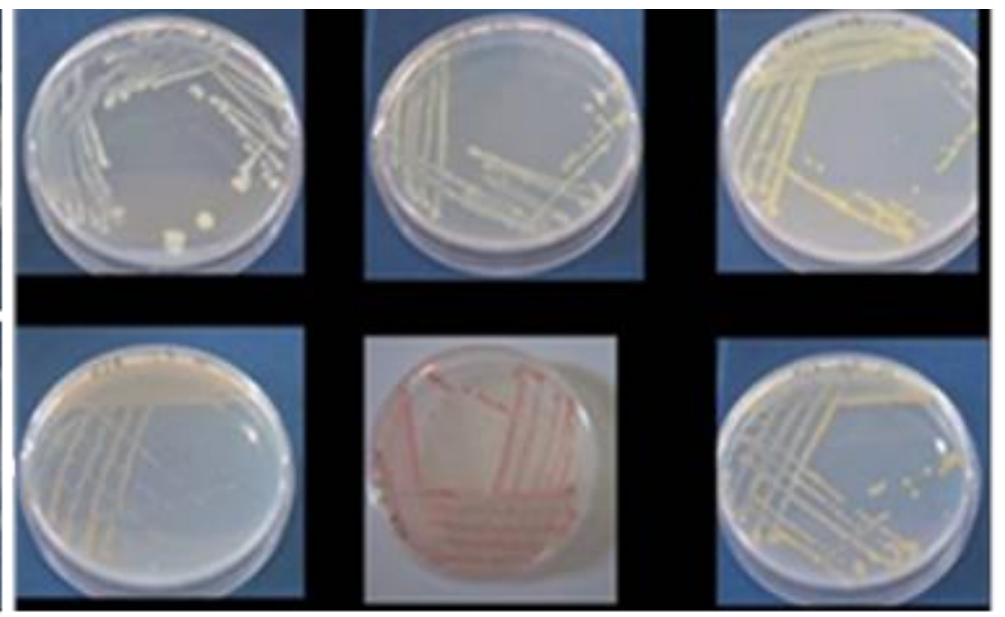


683

684

685

686

Table S1. Blast identification of sequenced (16S rRNA genes) of bacterial isolates from stonework from Sites 1 and 2, Portchester Castle, Portsmouth, UK. IS $1=$ Site 1; IS $2=$ Site 2; IS Pxx $=$ halotolerant isolates from site 1 .

\begin{tabular}{|c|c|c|c|c|}
\hline Isolate & Closest GenBank match & $\begin{array}{l}\text { Accession } \\
\text { number }\end{array}$ & $\begin{array}{c}\text { Max. } \\
\text { identity } \\
\%\end{array}$ & Reference \\
\hline IS 2q & Arthrobacter agilis DSM $20550 \quad$ (Soil) & NR_026198 & 99 & (Koch, et al., 1994) \\
\hline IS $1 \mathrm{~m} 1$ & $\begin{array}{l}\text { Bacillus vietnamensis } 15-1 \\
\quad \text { (Vietnamese fish sauce, halophile). }\end{array}$ & NR_024808 & 99 & (Noguchi, et al., 2004) \\
\hline $\begin{array}{l}\text { IS 1o } \\
\text { IS 1d } \\
\text { IS 2e } \\
\text { IS 2b }\end{array}$ & $\begin{array}{l}\text { Arthrobacter subterraneus } \mathrm{CH} 7 \\
\text { (Deep subsurface water) }\end{array}$ & NR_043546 & 100 & (Chang, et al., 2007) \\
\hline $\begin{array}{l}\text { IS 1g1 } \\
\text { IS 2g }\end{array}$ & Arthrobacter crystallopoietes DSM 20117 (Soil) & NR_026189 & 99 & (Koch, et al., 1994) \\
\hline IS 1e & Kocuria palustris TAGA27 (Plant rhizoplane) & NR_026451 & 98 & (Kovacs, et al., 1999) \\
\hline IS 1f1 & Kocuria rhizophila TA68 (Plant rhizoplane) & NR_026452 & 99 & (Kovacs, et al., 1999) \\
\hline $\begin{array}{c}\text { IS 1p } \\
\text { IS 1TQ1a } \\
\text { IS 2r } \\
\text { IS 2t1 } \\
\text { IS 2t2 }\end{array}$ & $\begin{aligned} \text { Bacillus muralis LMG } 20238 \\
\text { (Church mural, Germany) }\end{aligned}$ & NR_042083 & 99 & (Gorbushina, et al., 2004) \\
\hline IS 1TQ2f & Bacillus licheniformis DSM 13 & NR_074923 & 99 & (Rey, et al., 2004) \\
\hline $\begin{array}{l}\text { IS 1f2 } \\
\text { IS 1q } \\
\text { IS 1a }\end{array}$ & $\begin{array}{r}\text { Bacillus sp. M71_S10 } \\
\text { (Sediment, Mediterranean, Greece) }\end{array}$ & FM992819 & 98 & (Gaertner, et al., 2011) \\
\hline $\begin{array}{l}\text { IS } 1 \mathrm{~m} \\
\text { IS } 2 p\end{array}$ & Bacillus thuringiensis Bt407 & NR_102506 & 100 & (Sheppard, et al., 2013) \\
\hline IS $2 s$ & $\begin{array}{l}\text { Bacillus litoralis XWG1-5 } \\
\text { (Weathered city wall, Nanjing Ming City, China) }\end{array}$ & JN990412 & 95 & Unpublished \\
\hline IS A1 & Cellulosimicrobium funkei W6122 (Human) & NR_042937 & 99 & (Brown, et al., 2006) \\
\hline IS A2 & Streptomyces fulvissimus DSM 40593 & NR_103947 & 99 & $\begin{array}{l}\text { (Myronovskyi, et al., } \\
\text { 2013) }\end{array}$ \\
\hline IS A4 & Microbacterium oxydans $\mathrm{O}-5$ & JQ890539 & 100 & Unpublished \\
\hline $\begin{array}{l}\text { IS B1 } \\
\text { IS B6 }\end{array}$ & Micrococcus luteus NCTC 2665 & NR_075062 & 99 & Unpublished \\
\hline IS B4 & Gordonia terrae DSM 43249 & X79286 & 99 & (Klatte, et al., 1994) \\
\hline $\begin{array}{l}\text { IS P1 } \\
\text { IS P6 }\end{array}$ & Enterococcus faecium Aus0004 & NR_102790 & 99 & (Lam, et al., 2012) \\
\hline IS P2 & Pseudomonas fluorescens 1329 (Mango plant) & JN645965 & 100 & Unpublished \\
\hline $\begin{array}{l}\text { IS P3 } \\
\text { IS P4 } \\
\text { IS P5 }\end{array}$ & $\begin{array}{l}\text { Carnobacterium maltaromaticum LMA28 } \\
\text { (Soft cheese) }\end{array}$ & NR_102484 & 99 & $\begin{array}{l}\text { (Cailliez-Grimal, et al., } \\
\text { 2013) }\end{array}$ \\
\hline
\end{tabular}


Table S2. Blast identification of sequenced bacterial DGGE bands from stonework from Sites 1 and 2,

690

691

692 Portchester Castle, Portsmouth, UK. Uncult. represents an uncultured sequence.

\begin{tabular}{|c|c|c|c|c|}
\hline $\begin{array}{l}\text { DGGE } \\
\text { Bands }\end{array}$ & Closest GenBank match & $\begin{array}{c}\text { Accession } \\
\text { number }\end{array}$ & $\begin{array}{c}\text { Max } \\
\text { identity } \\
(\%)\end{array}$ & Reference \\
\hline 1a & $\begin{array}{l}\text { Uncult. Clostridiales clone A2 } \\
\text { (Medieval frescoes, Matera, Italy) }\end{array}$ & AM746680 & 97 & (Imperi, et al., 2007) \\
\hline $\mathbf{1 b} / \mathbf{3 a}$ & $\begin{array}{l}\text { Uncult. Chloroflexi clone CAR-BSb-E9 } \\
\text { (Wall of Carmona Roman Necropolis, Spain) }\end{array}$ & FN298047 & $98-99$ & Unpublished \\
\hline $\mathbf{2 a}$ & $\begin{array}{l}\text { Uncult. Chloroflexi clone 3-1AE9F10 } \\
\text { (Quartz Hypolith, Miers Valley, Antarctica) }\end{array}$ & HQ197602 & 99 & (Khan, et al., 2011) \\
\hline $4 \mathbf{a}$ & $\begin{array}{l}\begin{array}{l}\text { Uncult. Actinobacterium clone F15cmContig1 } \\
\text { (Solirubrobacter) }\end{array} \\
\begin{array}{r}\text { (Serpentinized dunite in Leka } \\
\text { ophiolite complex, Finland) }\end{array}\end{array}$ & JN003083 & 99 & Unpublished \\
\hline $\mathbf{5 a}$ & $\begin{array}{l}\text { Uncult. Bacteriodetes clone 0502TCLN356 } \\
\text { (Pontibacter saemangeumensis) }\end{array}$ & AB696088 & 98 & Unpublished \\
\hline $6 \mathbf{6}$ & $\begin{array}{l}\text { Uncult. Bacteriodetes clone EXPOSE_156B } \\
\text { (Epilithic, limestone cliff, UK) }\end{array}$ & HQ917840 & 97 & (Cockell, et al., 2011) \\
\hline $7 c$ & $\begin{array}{l}\text { Uncult. cyanobacterium clone UMAB-cl-44 } \\
\text { (Soil, Alexander Island, Antarctica) }\end{array}$ & FN811228 & 99 & (Chong, et al., 2012) \\
\hline $8 \mathbf{a}$ & $\begin{array}{l}\text { Uncult. Bacteriodetes clone JK1007 } \\
\text { (Marine diatom, Atlantic Ocean) }\end{array}$ & JX050172 & 87 & Unpublished \\
\hline $9 a / 33 a$ & $\begin{array}{l}\text { Uncult. Bacteriodetes clone JK1007 } \\
\text { (Marine diatom, Atlantic Ocean) }\end{array}$ & JX050172 & 96 & Unpublished \\
\hline $9 b$ & $\begin{array}{l}\text { Uncult. Bacteriodetes clone HglFeb0102m } \\
\text { (Seawater, North Sea) }\end{array}$ & JX016507 & 75 & (Teeling, et al., 2012) \\
\hline $\begin{array}{l}10 a / 11 a / \\
18 a / 18 b\end{array}$ & $\begin{array}{r}\text { Uncult. Bacteriodetes clone 5-36 (Gillisia) } \\
\text { (Desert, Xinjiang, China) }\end{array}$ & JQ712906 & 98 & Unpublished \\
\hline $12 \mathbf{a}$ & $\begin{array}{r}\text { Uncult. Actinobacteria clone P-8_B2 (Rubrobacter) } \\
\text { (Desert soil, Utah, USA) }\end{array}$ & HQ910304 & 99 & Unpublished \\
\hline 13a/19 & $\begin{array}{l}\text { Uncult. Deinococcales clone VB37 } \\
\text { (Chasmolithic community, Tibetan desert) }\end{array}$ & FJ790558 & 99 & Unpublished \\
\hline $14 a$ & $\begin{array}{l}\text { Uncult. Deinococcales clone 4B-WNS } \\
\text { (Weissenstein endolitc community, Switzerland) }\end{array}$ & AB374369 & 99 & Unpublished \\
\hline $15 a / 26 b$ & $\begin{array}{l}\text { Uncult. Bacterodietes clone RS15 } \\
\text { (Coastal saline soil, India) }\end{array}$ & HQ397356 & $89-90$ & (Yousuf, et al., 2012) \\
\hline $17 \mathbf{a}$ & $\begin{array}{r}\text { Uncult. Gemmatimonadetes clone TX4CB_148 } \\
\text { (Alkaline soil, lake Texcoco, Mexico) }\end{array}$ & FJ153017 & 90 & $\begin{array}{l}\text { (Valenzuela-Encinas, } \\
\text { et al., 2009) }\end{array}$ \\
\hline $20 a / 20 b$ & $\begin{array}{l}\text { Alpha-proteobacteria (Jannaschia rubra strain } \\
\text { CECT5088) }\end{array}$ & DQ915604 & $95 \%$ & Unpublished \\
\hline 21a & $\begin{array}{l}\begin{array}{l}\begin{array}{l}\text { Uncult. Beta-proteobacteria clone M80CK (Ralstonia } \\
\text { pickettii) }\end{array} \\
\text { (International Space Station Coolant) }\end{array}\end{array}$ & DQ497769 & $99 \%$ & Unpublished \\
\hline $22 a$ & $\begin{array}{l}\text { Uncult. Cyanobacteria clone C_5 } \\
\text { (Chroococcidiopsis) } \\
\quad \text { (Chasmolith, McKelvey Valley, Antarctica) }\end{array}$ & FJ490242 & 96 & $\begin{array}{l}\text { (Pointing, et al., } \\
\text { 2009) }\end{array}$ \\
\hline 23a & $\begin{array}{l}\text { Uncult. cyanobacterium clone DOL63 } \\
\quad \text { (Carbonate Rock, Guizhou Karst Region, China) }\end{array}$ & HM224428 & 83 & Unpublished \\
\hline 24a & $\begin{array}{l}\begin{array}{l}\text { Uncult. Cyanobacterium clone } \mathrm{H} 5-01 \mathrm{QJH} \\
(\text { Nostocales })\end{array} \quad \text { (prehistoric wall paintings) }\end{array}$ & EU434908 & $99 \%$ & (Portillo, et al., 2009) \\
\hline $32 \mathbf{a}$ & $\begin{array}{l}\begin{array}{l}\text { Marine Alpha-proteobacterium SIMO IS-S76-282 } \\
(\text { Palleroni })\end{array} \quad \text { (Salt marsh grass, Georgia, USA) } \\
\end{array}$ & AY149624 & 92 & (Buchan, et al., 2003) \\
\hline
\end{tabular}




\section{Supplementary References}

Brown JM, Steigerwalt AG, Morey RE, Daneshvar MI, Romero LJ \& McNeil MM (2006) Characterization of clinical isolates previously identified as Oerskovia turbata: proposal of Cellulosimicrobium funkei $\mathrm{sp}$. nov. and emended description of the genus Cellulosimicrobium. International Journal of Systematic and Evolutionary Microbiology 56: $801-804$.

Buchan A, Newell SY, Butler M, Biers EJ, Hollibaugh JT \& Moran MA (2003) Dynamics of bacterial and fungal communities on decaying salt marsh grass. Applied and Environmental Microbiology 69: 6676-6687.

Cailliez-Grimal C, Chaillou S, Anba-Mondoloni J, et al. (2013) Complete chromosome sequence of Carnobacterium maltaromaticum LMA 28. Genome announcements 1.

Chang H-W, Bae J-W, Nam Y-D, et al. (2007) Arthrobacter subterraneus sp. nov., isolated from deep subsurface water of the South Coast of Korea. Journal of Microbiology and Biotechnology 17: 1875-1879.

Chong CW, Convey P, Pearce DA \& Tan IKP (2012) Assessment of soil bacterial communities on Alexander Island (in the maritime and continental Antarctic transitional zone). Polar Biology 35: 387-399.

Cockell CS, Rettberg P, Rabbow E \& Olsson-Francis K (2011) Exposure of phototrophs to 548 days in low Earth orbit: microbial selection pressures in outer space and on early earth. ISME Journal 5: 1671-1682.

Gaertner A, Bluemel M, Wiese J \& Imhoff JF (2011) Isolation and characterisation of bacteria from the Eastern Mediterranean deep sea. Antonie Van Leeuwenhoek International Journal of General and Molecular Microbiology 100: 421-435.

Gorbushina AA, Heyrman J, Dornieden T, et al. (2004) Bacterial and fungal diversity and biodeterioration problems in mural painting environments of St. Martins church (GreeneKreiensen, Germany). International Biodeterioration \& Biodegradation 53: 13-24.

Imperi F, Caneva G, Cancellieri L, Ricci MA, Sodo A \& Visca P (2007) The bacterial aetiology of rosy discoloration of ancient wall paintings. Environmental Microbiology 9 : 2894-2902.

Khan N, Tuffin M, Stafford W, Cary C, Lacap DC, Pointing SB \& Cowan D (2011) Hypolithic microbial communities of quartz rocks from Miers Valley, McMurdo Dry Valleys, Antarctica. Polar Biology 34: 1657-1668.

Klatte S, Rainey FA \& Kroppenstedt RM (1994) Transfer of Rhodococcus aichiensis Tsukamura 1982 and Nocardia amarae Lechevalier and Lechevalier 1974 to the genus Gordona as Gordona aichiensis comb. nov. and Gordona amarae comb. nov. International Journal of Systematic Bacteriology 44: 769-773.

Koch C, Rainey FA \& Stackebrandt E (1994) 16S rDNA studies on members of Arthrobacter and micrococcus - an aid for their future taxonomic restructuring. FEMS Microbiology Letters 123: 167-171.

Kovacs G, Burghardt J, Pradella S, Schumann P, Stackebrandt E \& Marialigeti K (1999) Kocuria palustris sp. nov. and Kocuria rhizophila sp. nov., isolated from the rhizoplane of the narrow-leaved cattail (Typha angustifolia). International Journal of Systematic Bacteriology 49: 167-173.

Lam MMC, Seemann T, Bulach DM, et al. (2012) Comparative analysis of the first complete Enterococcus faecium genome. Journal of Bacteriology 194: 2334-2341. 
Noguchi H, Uchino M, Shida O, Takano K, Nakamura LK, Komagata K. (2004) Bacillus vietnamensis $\mathrm{sp}$. nov., a moderately halotolerant, aerobic, endospore-forming bacterium isolated from Vietnamese fish sauce. Int J Syst Evol Microbiol. 54:2117-20.

Pointing SB, Chan Y, Lacap DC, Lau MCY, Jurgens JA \& Farrell RL (2009) Highly specialized microbial diversity in hyper-arid polar desert. Proceedings of the National Academy of Sciences of the United States of America 106: 19964-19969.

Portillo MC, Alloza R \& Gonzalez JM (2009) Three different phototrophic microbial communities colonizing a single natural shelter containing prehistoric paintings. Science of The Total Environment 407: 4876-4881.

Rey MW, Ramaiya P, Nelson BA, et al. (2004) Complete genome sequence of the industrial bacterium Bacillus licheniformis and comparisons with closely related Bacillus species. Genome Biology 5.

Sheppard AE, Poehlein A, Rosenstiel P, Liesegang H \& Schulenburg H (2013) Complete Genome Sequence of Bacillus thuringiensis Strain 407 Cry. Genome announcements 1.

Teeling H, Fuchs BM, Becher D, et al. (2012) Substrate-controlled succession of marine bacterioplankton populations induced by a phytoplankton bloom. Science 336: 608-611.

Valenzuela-Encinas C, Neria-Gonzalez I, Alcantara-Hernandez RJ, Estrada-Alvarado I, Zavala-Diaz de la Serna FJ, Dendooven L \& Marsch R (2009) Changes in the bacterial populations of the highly alkaline saline soil of the former lake Texcoco (Mexico) following flooding. Extremophiles 13: 609-621.

Yousuf B, Sanadhya P, Keshri J \& Jha B (2012) Comparative molecular analysis of chemolithoautotrophic bacterial diversity and community structure from coastal saline soils, Gujarat, India. BMC Microbiology 12: 150. 